\title{
Failure of Temporary Contracting in Spain as a Measure to Promote Employment
}

\author{
Sara Ruano-Albertos \\ Universitat Jaume I, Castellón de la Plana, Spain \\ Email: ruanos@uji.es
}

How to cite this paper: Ruano-Albertos, S. (2020). Failure of Temporary Contracting in Spain as a Measure to Promote Employment. Beijing Law Review, 11, 626-635. https://doi.org/10.4236/blr.2020.112038

Received: April 27, 2020

Accepted: June 20, 2020

Published: June 23, 2020

Copyright $\odot 2020$ by author(s) and Scientific Research Publishing Inc. This work is licensed under the Creative Commons Attribution International License (CC BY 4.0).

http://creativecommons.org/licenses/by/4.0/ (c) (i) Open Access

\begin{abstract}
High dismissal has reduced hiring in job creation. This is why temporary contracting has been used as a technique to overcome these business reluctances. However, this objective has not been fulfilled. Indeed quite the opposite in fact as the labour market has generally become precarious. The ultimate outcome is a widened inequality gap and workers' poverty.
\end{abstract}

\section{Keywords}

Temporary Hiring, Precariousness, Unemployment, Social Policy

\section{Introduction}

Temporary hiring has become one of the main axes of the continuous flexibilisation process of Spanish regulations in an attempt to lower the chronic unemployment rates of the Spanish labour market to get on top of business people's concerns about their production requirements. Permanent contracts (the preferential form of hiring according to regulations currently in force) have been relegated and reach almost insignificant rates.

This research work chronologically indicates the different regulatory reforms made to temporary hiring. Each reform is presented with available data about its effects on job creation. The conclusion reveals that, far from fulfilling the initial objective; what has actually happened is that the Spanish labour market has been continuously made precarious, which affects most of the working class. Unemployment figures soared during the crisis, and what should be the main objective of suitable social politics has been blatantly ignored: facilitating quality work as a mechanism to fight inequality and poverty. 


\section{Promoting Temporary Hiring as a Measure to Promote Employment. Regulatory Stages and Their Outcomes}

The flexibility process of Spanish occupational regulations has been basically motivated by an attempt to appeal to businesspeople more in order to promote and increase hiring, while lowering high unemployment rates, which Spain has always had more or less similar rates. In fact, these attempts have given way to amendments being continuously made to regulations, which have not always met the desired objective. Nevertheless, the traditional full-time hiring model of indefinite duration has been left to one side to favour temporary part-time hiring, which is currently the main feature of the present Spanish hiring system. In fact the temporary characterisation of a job refers to the specific duration of contractual obligations to which parties are submitted, whose applicability is subjected to the established term ending. Temporary work is related to the total duration of a labour relation, which is the opposite to one of indefinite duration.

\subsection{Stage 1: From the Spanish Transition to the Verge of the Liberalisation Starting (1980-1993)}

It is worth remembering that the Workers Statute (WS) started to establish the work stability principle by prioritising indefinite over temporary hiring, and by implementing temporary hiring in those specific assumed cases in which the reason for such hiring was justified: Article 15 of the WS. Therefore, as temporary contracting had to be justified, it was impossible to establish the number of temporary workers that a company had to have, and this had to depend on there being an effective reason for such hiring, and temporary contracting could only take place when the assumptions foreseen by law actually came into being. Nonetheless, the wording employed in some assumed cases (15.1b; WS) was quite extensive: market circumstances, accumulating tasks and too many orders which doubtlessly aimed to encourage hiring and to respond to the very high unemployment rates at that time. Moreover, Article 17.3 of the WS included the possibility of the government being able to regulate measures related to reserving, duration or preference in employment in order to facilitate the hiring of certain groups of workers. So it authorised temporary hiring with no specific justification as a measure to encourage employment. The unemployment rate in 1980 was $12.43 \%^{1}$.

Despite the efforts made to lower unemployment rates, 4 years later they reached $21.1 \%^{2}$, with $24.6 \%$ for women and $19.6 \%$ for men, and were significantly higher for young people at $44.57 \%{ }^{3}$. This obliged the lawmaker to perfect hiring formulae in an attempt to create as many job posts as possible. These formulae included temporary hiring and part-time hiring (Ruano-Albertos, 2017).

${ }^{1}$ INE. Working population survey, 1980.

${ }^{2}$ INE. Working population survey, 1984.

${ }^{3}$ INE. Working population survey, 1984. 
Therefore, the reform made by Law 32/1984, of 2 August, on modifying certain articles in Law 8/1980, was justified as indicated in its Preamble by the need for the "...adaptation of the institutional frame regulating the labour market to some new circumstances of the Spanish economy after the economic crisis in the last 10 years". This constituted the pressing demand to create as many jobs as possible, and was a fundamental and priority objective of the government's programme. Consequently, temporary hiring was promoted as a measure to encourage employment, which was regulated more clearly with more legal security by introducing a new way of temporary hiring when a new working activity was launched for the first 3 years that it remained. Here the idea was to reduce the risks of new investments while feasibility perspectives for these working activities were unavailable in order to well establish them. Moreover, given the very high unemployment rates for young adults, encouragement was made to hire them using the contracts employed in placements and for training, and there was a new feature: the relief contract. In this way, contracts could: form part of placements and training by extending their maximum duration to 3 years, and by extending the subsequent period to 4 years after becoming qualified, during which the on-the-job training/employment contract was signed. Likewise, the maximum age limit was raised to 20 years for training contracts; this limit was not considered for disabled workers, and part of the working day was cut for workers so they could continue with their education.

Despite the drive behind such contracts, the response was not the intended one because unemployment rates in successive years were still very high, i.e., $21.48 \%{ }^{4}$ in 1985 and $23.83 \%$ in 1993 , despite temporary contract hiring increasing from 1985 to 1993, with some 2 million contracts in absolute terms going from 2,547,611 in 1985 to 4,432,547. Doubtlessly this legal framework favoured a high temporary hiring rate, which was 3-fold the figures elsewhere in Europe. Indeed temporary hiring in Spain in 1990 represented 29.8\%, while it was $10.2 \%$ in the EU15. So it was that the high incidence of temporary hiring helped a large group of workers to form with unstable jobs, very little protection when their contracts ended, low salaries, and scarce or no training offered to them by businesspeople. More temporary contracts were signed by the female population than by men. In 1993, 37.2 per 100 of working women had a temporary contract, as opposed to 29.8 per $100 \mathrm{men}^{5}$. This led to a series of employment measures being taken; e.g. Royal Decree Law 3/1993, of 26 February, in an attempt to relieve the situation, which dealt with certain aspects related to regulating temporary hiring to promote employment by allowing temporary contracts, which last as long as legally possible, being continued for another year up to a 4-year period. Employers were encouraged to make these temporary contracts indefinite after 4 years and the companies that did so were subsidised.

\footnotetext{
${ }^{4}$ Source: EPA. Historic series.

${ }^{5}$ Report on women's situation in the Spanish socio-occupational reality. Approved during a Socio-Economic Board meeting on 19 October 1994.
} 


\subsection{2nd Stage: The First Steps in the Liberalisation by Empowering Collective Negotiation (1994-1996)}

The seriousness of the economic situation and its incidence on the labour market meant having to pass another reform, Law 10/1994, of $10 \mathrm{May}$, and the subsequent law 11/1994, of 19 May, with the same objective: that of fighting unemployment and creating jobs by including more flexibility in labour relations. In line with temporary hiring, attempts were made to adapt to companies' requirements, albeit by stressing the necessary casualty of temporary hiring and stressing the importance of collective negotiation. So once again, modifications were made in both temporary hiring and part-time hiring (Ruano-Albertos, 2019: p. 19), whereas non-causal hiring to promote employment disappeared, which had been introduced into the 1984 reform, and boiled down to certain specific cases: workers aged over 45 years, being unemployed for more than 1 year, disabled workers, etc.. However, temporary hiring was favoured by means of part-time work employment agencies which justified their action given the need to adapt Spanish occupational regulations to current labour market demands and the European reality. Thus hiring workers to temporarily offer them to other companies in order to meet current requirements actually became a major change because it involved introducing a form of labour provision that was far removed from the hiring model maintained until that time.

Nonetheless, unemployment rates were still high for the following years: 1993 (22.73\%); 1994 (24.17\%); 1995 (22.93\%); $1996(22.21 \%)^{6}$. The pursued objective of encouraging occupational stability through indefinite hiring, by promoting active employment policies, was not met. The number of temporary contracts went from 2,547,611 in 1985 to 4,432,547 in 1993. Between 1994 and 1997, temporary hiring rose by $7 \%$, which went from $31.36 \%$ in 1994 to $37.23 \%$ in $1997^{7}$. In 1997, temporary hiring by means of temporary work agencies doubled, which meant that about $14 \%$ of temporary hiring was carried out by these companies ${ }^{8}$.

\section{3. $3^{\text {rd }}$ Stage: The Role of Social Agreement in the Normative Change towards a Stable Hiring Model (1996-2007)}

As result of the social dialogue politics promoted by the government, business organisations CEOE and CEPYME and Trade Unions CC.OO and UGT signed the Interconfederal Agreement for Stable Employment on 28 April 1996. This document proposed contributing to companies' competitiveness, improving employment, and reducing/rotating temporary hiring. It recognised that employment was the result of many variables, including a suitable economic policy that actually promoted it, and a suitable framework of labour relations that allowed more flexibility, while making employment more permanent. So it actually directed the promotion of employment towards stabler hiring. In so doing, an

${ }^{6}$ Source: INE. 1997 Yearbook. INE documents.

${ }^{7}$ Source: INE. 1997 Yearbook. INE documents. Yearbook of Occupational Statistics, Ministry of Work and Social Affairs.

${ }^{8}$ Source: EPA. Historical series. 
attempt was made to change the previous hiring policy, which had basically focused on temporary hiring as in the legal modifications made as of 1984. The result of the above-cited agreement was that Law 63/1997 was passed with urgent measures to improve the labour market and to encourage indefinite hiring, and challenges were marked by high unemployment rates for young adults and a considerable increase in temporary hiring. This meant that measures were taken to, on the one hand, favour labour insertion and theoretical-practical training for young adults and, on the other hand, specify and restrain assumed cases of contracting labour, particularly as regards manual work or services, as well as provisional hiring based on production circumstances. Temporary hiring for launching new activities ended. A change was also made in the hiring model to encourage employing those groups facing certain difficulties. Briefly, the measures taken to promote employment basically addressed stabler employment for the unemployed and to convert temporary contracts into indefinite ones. The pursued philosophy was the same: to lower unemployment rates while favouring a change in the existing direction to favour indefinite contracts. However, the taken measures still did not lead to the desired results. Regulations in favour of stable employment continued, despite insistence on the need for a flexible labour market.

In Europe after the Treaty of Amsterdam came into force, European social agents signed an Agreement on 18 March 1999 about temporary work contracts $^{9}$, as set out in an Annexe in Directive 1999/70/EE, of 28 June. What this agreement intended was to avoid possible discriminations in work conditions by establishing a framework to favour temporarily hired workers being treated the same. In parallel, the importance of such contracts was stressed to meet business requirements in certain sectors or occupations, despite considering that indefinite work contracts were those which contributed to both workers' quality of life and their improved performance.

Notwithstanding, the essential problems of the Spanish labour market continued because the temporary hiring rate still exceeded $33 \%{ }^{10}$. The most widely used contracts were still temporary, and hiring people for manual work or services followed the same trend as that of previous years. What is more, the number of temporary contracts increased, especially short-term hiring; the reason for lay in increased part-time hiring, which was essentially temporary and not indefinite ${ }^{11}$. Therefore, in order to redirect the situation towards stabler employment, the subsequent regulation once again considered encouraging stable employment. Law 12/2001, of 9 July, with urgent measures to reform the labour market in order to increase employment and improve its quality, contemplated Directive 1999/70/EC on temporary employment and, although a new temporary

\footnotetext{
${ }^{9}$ Framework Agreement about temporary employment, signed on 18 March 1999, which comes as an Annexe in Directive 1999/70/EE of 28 June. It sets out the minimum conditions for temporary work contracts.

${ }^{10}$ Source: EPA. Historical series.

${ }^{11}$ Source: EPA. Historical series.
} 
contract was introduced, the so-called insertion contract, it also well-established the use of contracts to encourage indefinite hiring by indicating more assumed cases. In this iter, Law 45/2002, of 12 December, with urgent measures to reform the protection system for unemployment and to improve occupation, once again stressed stable employment in an attempt to avoid repeated, abusive or fraudulent temporary contracts. Even though the measures taken in recent years had obtained positive results as stable employment increased somewhat, temporary hiring was still very high. The temporary hiring rate was very high at $31 \%{ }^{12}$ at the end of 2002. Given this situation, it was evident that lines of action capable of promoting stable employment were necessary, and also managing a temporary hiring framework that would suitably respond to present production requirements.

The grave concern about high temporary hiring rates once again led to social dialogue being used as an instrument capable of responding to this serious situation. As a result of this dialogue, the Interconfederal Collective Negotiation Agreement was signed in $2003^{13}$, which considered which main lines had to be followed, and included the leading role that collective negotiation had to play; promoting indefinite hiring was also essential: companies' permanent needs had to be covered by indefinite contracts and their present requirements by temporary contracts, without forgetting adopting formulae in order to avoid any unjustified series of successive temporary contracts. All in all, this clearly shows just how unfruitful the policies made until that time actually was.

\subsection{4th Stage: Squaring the Circle. Creating Stable Jobs in the Economic Crisis Context (2009-2014)}

Forthcoming years were marked by the last economic crisis, which did not favour any improvements being made to the labour market. Loss of jobs and excessive temporary hiring ${ }^{14}$ continued to be the common denominator of the time given the marked economic recession that was taking place. Unemployment rates continued to rise: last quarter of 2009 (18.66\%); last quarter of 2010 (20.11\%); last quarter of 2011 (22.56\%); last quarter of 2012 (25.77\%); last quarter of $2013(25.73 \%)^{15}$. These rates clearly evidence the grave situation that Spain was in. Efforts were naturally directed to promote employment ${ }^{16}$, but of a stabler kind. We should remember that the crisis had considerably reduced the mean duration of temporary contracts and, in turn, the mean duration of the whole

\footnotetext{
${ }^{12}$ Commission staff working paper: Assessment of the implementation of the 2002 employment guidelines. Supporting document to the Joint Employment Report 2002. COM (2002) 621 final.

${ }^{13}$ Interconfederal Collective Negotiation Agreement in 2003, 30 January 2003, signed by CEOE, CEPYME, CCOO and UGT.

${ }^{14}$ Almost 4.5 million temporary contracts lasting less than 1 month were registered in 2009. In 2009, of all the registered requests for tax-paying unemployment benefit due to work contracts ending, 56 per 100 were terminated temporary contracts. CES 2009 Report.

${ }^{15}$ EPA. Historical series.

${ }^{16}$ In the Agreement for Employment and Collective Negotiation of 2010, 2011 and 2012, signed on 9 February 2010 by (CEOE), (CEPYME), (CC.OO.) and (UGT).
} 
initial temporary hiring, which was 63 days $^{17}$. This meant that the philosophy followed to favour stabler job creation led to Law 35/2010, of 17 September, with urgent measures to reform the labour market, whose objective was to reduce the duality of the Spanish labour market by adopting measures that tended to restrict, on the one hand, the unjustified use of temporary hiring and, on the other hand (as set out in its Presentation of Reasons), to favour indefinite hiring. Among the measures taken to restrict the unjustified use of temporary hiring, a temporary and maximum limit was set in contracts signed for certain manual work or services, by means of which such contracted work would be considered permanent. Likewise, in order to dissuade temporary hiring, compensation rose to 12 worked days when the most widely used temporary contracts ended, and adjustments were made to the regulation passed in 2006 to avoid successive series of temporary contracts being signed to make this regulation more efficient. Nonetheless, this regulation was temporarily suspended in $2011^{18}$ because the given situation at the time had undesirable effects caused by temporary contracts not being renewed, which would have a negative effect on employment continuing.

Unfortunately, the 2010 labour reform did no manage to reduce either employment or temporary hiring. The economic crisis of the time and its strong impact on some activities were determining factors of jobs being destroyed. Indeed in 2011, job losses were so severe that indefinite employment considerably dropped. The number of workers who lost indefinite employment came to 402,000 in 2012, which is a drop of $3.6 \%$ of the annual mean compared to the year before ${ }^{19}$, and temporary employment also lowered. The temporary hiring rate lowered to $23.6 \%$, which was almost 3 points less than the year before ${ }^{20}$. Notwithstanding, the temporary hiring rate was still extremely high, especially for young adults ${ }^{21}$ under the age of 25 years. Once again the duration of temporary contracts became shorter ${ }^{22}$. The sectors most negatively affected by this situation were the building sector, the manufacturing sector and the services sector, especially hotel trade.

With a view to favour job creation, promote indefinite hiring and drive internal flexibility, Law 3/2012, of 6 July, was passed. This law, for which no consensus was reached with social partners, led to a major amendment to the WS in, among others, matters referring to ways to hire, internal/external flexibility, labour intermediation, incentives to hire and professional training towards employment, and also in negotiation issues: regulations on determining the negotiation structure and consensus among agreements, as well as an agreement re${ }^{17}$ CES 2011 Report.

${ }^{18}$ Royal Decree Law 10/2011, of 26 August, on urgent measures to promote employment for young adults, encourage stable employment and maintain the professional requalification programme of people whose unemployment benefit had ended.

${ }^{19}$ Source: INE, Working population survey.

${ }^{20}$ Source: INE, Working population survey.

${ }^{21} 62 \%$ of people under the age of 25 were temporarily hired. Source: Eurostat Database.

${ }^{22}$ In the mean number of days, this reduction was 3.6 for all temporary contracts. SEPE. 
maining in force until a new one was signed. Regarding ways to hire, and to encourage indefinite hiring, a new indefinite contract was introduced for companies with fewer than 50 workers whose distinguishing characteristics lay in the time the workers' test period lasted, which was set at 1 year, along with a series of tax incentives for companies and reductions in the Social Security payments that businesses paid, plus other certain requirements and for given groups. Modifications were also made to the legal part-time hiring regime, while the contract to promote indefinite hiring was done away with. Another important aspect of this reform had to do with lowering the amount paid to compensate wrongful dismissal. Nonetheless, and despite this series of flexibilising measures for the labour market, 2013 started with a very high unemployment rate (26.1\%). The long-term unemployed (50.4\%) and dismissed young adults (55.5\%) were still victims of the highest unemployment rates $^{23}$. Consequently, the later law, namely Law 11/2013, of 26 July, on measures to support entrepreneurs and to stimulate growth and job creation, was yet another attempt to lower the aforementioned rates, and encouraged hiring young adults by reducing the amount of Social Security payments that businesses paid for microenterprises that engaged in indefinite hiring. Furthermore, part-time hiring was encouraged if it was linked with unemployed young people's training. The use of part-time hiring even increased by improving certain aspects of part-time workers' social protection with Law 1/2014, of 28 February, Royal Decree Law 3/2014, of 28 February, on flexible measures that continued with Royal Decree Law 16/2013, of 20 December, which included relevant changes about flexibility in organising the times worked in part-time hiring, and affected various aspects of its legal regime to thus favour this way of hiring becoming more widely used as an ideal formula to improve companies' productivity. These measures encouraged part-time hiring, which became the most important way to hire workers. However, this increase basically took place in part-time temporary hiring as $34.7 \%$ of temporary contracts were part-time jobs. The mean duration of temporary hiring in days was cut once again ${ }^{24}$.

\subsection{5th Stage: Resisting Temporary Hiring Rates (2015-2018)}

The temporary hiring rate in successive years continued to be high. In $2014^{25}$ it was $24.2 \%$ and its mean duration in days was even shorter. In $2015^{26}$ this rate was $25.2 \%$, and $30.9 \%$ of people with a temporary contract were aged under 30 years. In $2016^{27}$, it rose to $261 \%$ and to $47.8 \%$ for those aged under 30 years. In $2017^{28}$ it was $26.7 \%$ and the shorter duration trend of this hiring continued, with $28.5 \%$ of signed contracts lasting 1 week or less.

The need to fight against precarious employment (Casas Baamonde, 2017),

${ }^{23} \mathrm{INE}$, Working population survey. Historical series.

${ }^{24}$ CES 2013 Report.

${ }^{25}$ CES 2014 Report.

${ }^{26}$ CES 2015 Report.

${ }^{27}$ CES 2016 Report.

${ }^{28}$ CES 2017 Report. 
and more specifically against abuse in short temporary hiring (Sala Franco \& López Terrada, 2017), led to Royal Decree Law 28/2018, of 28 December, to revalue public pensions and other urgent social, occupational and employment matters, namely a series of Social Security measures. The intention of these measures was to: on the one hand, place those workers with such contracts on the same level in social protection terms (Moreno Romero, 2019: p. 115) as those with longer lasting contacts; on the other hand, to increase tax payments in these contracts as a dissuasive measure for businesspeople. As the unemployment rate in Spain had gone below 15\%, the initiatives made in the Spanish regulation framework on work contracts, and conditioned to these tax payments, were revoked. Even though the unemployment rate had dropped to $14.55 \%{ }^{29}$, in 2018 the temporary hiring rate was $26.8 \%$, it was $26.9 \%$ in the fourth quarter of 2018 , and was around $71 \%{ }^{30}$ for young adults under the age of 30 .

\section{Conclusion}

We have seen that, despite successive strategies being adopted to activate employment, the presented data clearly reveal temporary hiring and a marked rotation in the labour market predominate, along with an obvious difficulty to create stabler jobs. Temporary hiring has not helped to lower unemployment rates, the assumed objective of a policy that made an exception with the general rule of favouring permanent job contracts. Outsourcing (Vicente-Palacio, 2016, 2018), which is usually resorted to by companies to integrate their productive activity (Falguera Baró, 2015: p. 10), and using temporary work agencies to cover vacancies, has inevitably contributed to increasing temporary hiring, whose duration is mostly short.

Precarious working conditions and low salaries cannot continue to support the labour market. With this new framework, it is necessary to promote stable employment which, as we see it, cannot come up against more productivity, but quite the reverse in fact. We ought not to forget that Spanish regulations prioritise not only the stable employment principle, but also indefinite hiring over temporary hiring insofar as temporary hiring is only acceptable in certain assumed cases with a justified temporary hiring cause. In fact the Work Inspection Department ${ }^{31}$ has intensified the fight against the fraudulent use of such contracts (Ballester-Pastor, 2019: p. 137); this is demonstrated by continuous actions that intend to avoid temporary hiring going against the law. According to 2017 data $^{32}$, the result of such action was that approximately 92,925 temporary work contracts that went against the law were converted into indefinite ones, which is a good indication of its fraudulent use.

Consequently, accurate measures must be taken to avoid any abuse and fraud

${ }^{29} \mathrm{INE}$, Working population survey.

${ }^{30}$ Report no. 17 Young people, June 2018. Ministry of Work, Migration and Social Security.

${ }^{31}$ Master Plan for dignified work. State Inspection Agency belonging to the Ministry of Work and Social Security. Subsecretary of Employment and Social Security. State Inspection Agency of Work and Social Security. April 2018. Work and Social Security.

${ }^{32}$ Strategic Plan of Inspection of Work and Social Security, 2018-2020. 
when business people use such ways to hire workers when the justified causes for them do not coincide. Spain continues to register a higher percentage of temporary hiring, and the risk of workers with such contracts being poor is, according to the $\mathrm{EU}^{33}$, 3-fold higher than for workers with indefinite contracts. Spain cannot remain at the top of the list of EU countries with the highest poverty levels. Therefore, in order to make the flexibility of labour regulations compatible with ensuring dignified working conditions, this objective must be fundamental for both the government and social partners.

\section{Acknowledgements}

This research forms part of Research Projects European Social Jurisprudence and Spanish Law: present, past and future (IP: Arántzazu Vicente Palacio), Research promotion plan UJI (2020-22).

\section{Conflicts of Interest}

The author declares no conflicts of interest regarding the publication of this paper.

\section{References}

Ballester-Pastor, I. (2019). Nuevas formas de trabajo autónomo y su protección social: contenido, alcance y retos pendientes" en RUANO-ALBERTOS (Dir). Nuevas formas de acceso al empleo, Barcelona (Atelier).

Casas Baamonde, M. E. (2017). La contratación temporal: problemas y soluciones. Un debate necesario. Madrid: Derecho de las Relaciones Laborales.

Falguera Baró, M. Á. (2015). La externalización y sus límites. Albacete: Bomarzo,

Moreno Romero, F. (2019). El impulso y eficacia de las políticas públicas de promoción del autoempleo y emprendimiento: Una visión crítica desde la perspectiva de la Seguridad Social, en AA. VV. Atelier, Barcelona: Nuevas formas de acceso al empleo.

Ruano-Albertos, S. (2017). El contrato a tiempo parcial: Las posibles perversiones en su utilización. Revista General de Derecho del Trabajo y de la Seguridad Social, 46, Online.

Ruano-Albertos, S. (2019). El contrato a tiempo parcial: su utilización como <modelo> de contratación laboral en el actual mercado de trabajo, en AA.VV. Atelier, Barcelona: Nuevas formas de acceso al empleo.

Sala Franco, T., \& López Terrada, E. (2017). Propuestas para un debate sobre la reforma de la contratación temporal. Madrid: Derecho de las Relaciones Laborales.

Vicente-Palacio, A. (2016). Empresas multiservicio y precarización del empleo. Barcelona: Atelier.

Vicente-Palacio, A. (2018). Changes in Productive Organisation, Outsourcing and Multiservice Companies (A New Workers' Category: “Sub-Ceded” Worker). Beijing Law Review, 9, 255-274. https://doi.org/10.4236/blr.2018.92017

\footnotetext{
${ }^{33} 2020$ European Semester: Assessment of progress on structural reforms, prevention and correction of macroeconomic imbalances, and results of in-depth reviews under Regulation (EU) No 1176/2011. Country Report Spain 2020. Brussels, 26.2.2020 SWD (2020) 508 final.
} 